\title{
FRAMEWORK FOR INDICATOR-BASED OPTIMIZATION OF DISASTER RISK MANAGEMENT IN LOCAL COMMUNITIES
}

\author{
UDC 005.334:504.4:519.8
}

\author{
Goran Janaćković1 ${ }^{\text {, Suzana Savić }}{ }^{\text {, Miomir Stanković }}{ }^{2}$ \\ ${ }^{1}$ University of Niš, Faculty of Occupational Safety in Niš, Niš, Serbia \\ ${ }^{2}$ Mathematical Institute of the Serbian Academy of Sciences and Arts, Belgrade, Serbia
}

\begin{abstract}
The effects on functioning of the society and consequences of natural disasters and technological accidents require preparedness and rapid response. Disaster management is defined by decisions based on situation description and potential dangers. Risk assessment is performed at various levels, from national to local. This paper presents a framework to optimize natural disaster and technological accident risk management at local level based on application of risk indicators. The method of multi-criteria analysis is applied, and key indicators that best describe the risks at the level of local communities in Serbia were chosen. The results show the importance of raising the resilience of local communities to disasters, primarily in the areas of planning and capacity building.
\end{abstract}

Key words: indicators, risk, resilience, management, fuzzy AHP

\section{INTRODUCTION}

Although the effectiveness of preventive measures, taken to reduce the number and consequences of extraordinary events, is high, the risks of disasters continue to grow, as well as the number of technological, anthropogenic or natural events, which have had a significant negative impact on life activities of people, functioning of the economy, social aspects, and the environment. Therefore, it is necessary to continuously increase the balance of responsibilities and capacity for disaster management.

Disaster management emphasizes prevention, social protection of population and property from destructive forces of natural and anthropogenic disasters, through comprehensive program of risk reduction, preparedness, response and recovery [1]. Adequate disaster management requires timely and good decisions, and they should be supported by adequate indicators, whose values indicate a way to prevent and/or respond

Received March 19, 2017 / Accepted May 12, 2017

Corresponding author: Goran Janaćković

University of Niš, Faculty of Occupational Safety in Niš, Čarnojevića 10a, 18000 Niš, Serbia

E-mail: goran.janackovic@znrfak.ni.ac.rs 
to different threats [2-7]. This led to application of advanced methods, techniques and tools for decision-making in emergency situations.

One of the definitions of disaster management says it is "a risk management so that societies can live with natural and technical hazards, and control disasters caused by them" (Waugh, 2000, in [1]). Therefore, disaster management is connected to corresponding risk management.

Methods of multi-criteria analysis provide necessary support for decision-making in relation to disasters [8-14]. They are applied for the selection of key performance indicators of safety systems or identification of significant risks on the basis of available data sets. The key problem with the data on disasters is lack of standardized methodologies for data collection and lack of definitions. Information collected from various public sources is not originally collected for statistical purposes. Thus, even when a strict definition of catastrophic events and parameters during the processing of the data is applied, public institutions do not process the data adequately. In addition, the data is not always complete for each disaster. Data quality can be different, based on the type of a disaster, or the location of origin.

Due to the fact that in the period 2012-2016 four natural disasters on the entire territory of the Republic of Serbia and over 20 emergencies at the community level were declared, definition of criteria and key indicators of resilience and risk at local level in the Republic of Serbia is a necessity. During the definition of indicators, we used the results of previous studies [1-7], as well as the requirements of national legislation in this area.

The aim of this paper is to highlight the importance of indicators for disaster management, define resilience and risk indicators that can be used at the community level in the Republic of Serbia, and determine their preference by applying the fuzzy AHP method.

\section{METHOD}

The methodology for assessing the resilience and risk recommends the use of elementary and combined indicators at local level. The aim is to provide decision-makers access to information they need to identify risks and propose adequate policies and actions for risk management in emergency situations. The system of indicators should allow the identification of economic and social risk factors, as well as risk management and international comparison of these factors. Creating a measurement system based on indicators is major conceptual and technical challenge, due to the fact that we should establish indicators that are transparent, strong, representative, convertible, comparable and easy to understand.

The methodological framework for disaster risk management at local level is based on application of risk indicators and multi-criteria analysis. Optimization of disaster management at local level involves raising the resilience of local communities in emergency situations and risk management in emergency situations. Increasing resilience and reducing the vulnerability of local communities can be achieved by corresponding processes of planning, resource management, and increase of technical/technological and socio-economic security. The quality of risk management depends on the type of potential disaster, capacity of protection and rescue in emergency situations, existing legislation and defined policies. The framework is shown in Figure 1. 


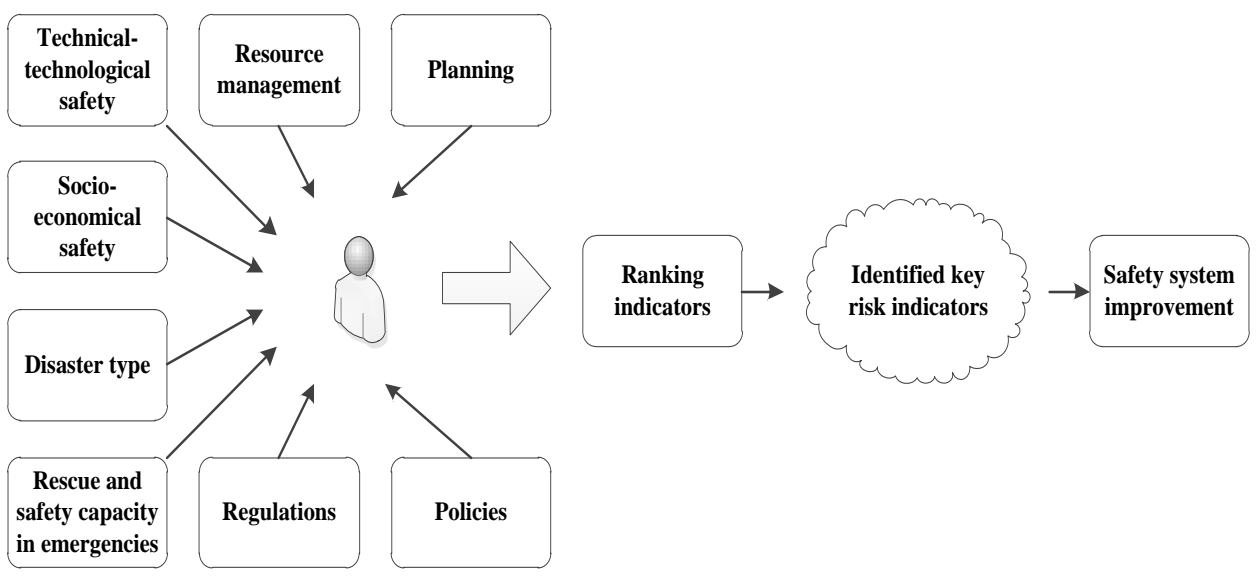

Fig. 1 Proposed framework for disaster risk management in local communities.

Bearing in mind national regulations on emergency situations in Serbia, as well as contemporary research in this area [11, 15-19], for previously mentioned processes and quality elements of disaster risk management, the following indicators are defined, as presented in Table 1.

Indicators are grouped into seven categories: planning, resource management, technical/technological security, socio-economic security, type of emergency, protection and rescue capacities in emergency situations, laws and regulations, and policies. Given that all these indicators do not have the same importance for the optimization of disaster management, it is necessary to rank them according to their importance.

For the purposes of ranking the indicators, the fuzzy analytic hierarchy process (fuzzy AHP) is applied. Fuzzy AHP method is an extension of plain AHP method [10-12], in which the estimates of experts are presented in a form of fuzzy numbers. Application of fuzzy numbers for evaluation of indicators helps more realistic representation of the problem of emergency management. An additional advantage of the fuzzy AHP method is the possibility of describing the characteristics of the system using a range of values, which makes the comparison more realistic in relation to the comparison in which it is necessary that experts select specific value describing the relationship between two alternatives.

The fuzzy AHP method is based on matrix theory and fuzzy arithmetic. We applied triangular fuzzy numbers, defined as $F=\left\{\left(x, \mu_{F}(x)\right), x \in R\right\}$ where $x \in(-\infty,+\infty)$, and $\mu_{F}(x):(-\infty,+\infty) \rightarrow[0,1]$ is a continuous function. Triangular fuzzy number can be notes as $M=(l, m, u)$, or as $\tilde{a}$. 
Table 1 Proposed disaster risk management indicators at the local community level.

\begin{tabular}{|c|c|}
\hline $\begin{array}{l}\text { Group of } \\
\text { indicators }\end{array}$ & Indicators \\
\hline Planning $\left(R_{1}\right)$ & $\begin{array}{l}\text { - The adoption of security strategy at the local community level (town, } \\
\text { municipality) }\left(R_{11}\right) \\
\text { - Development of risk assessment of natural and other disasters (floods, } \\
\text { landslides, extreme temperatures, chemical accidents) }\left(R_{12}\right) \\
\text { - Development of plans for protection and rescue in emergency situations (contain } \\
\text { specific protection measures, such as the construction of embankments, regulation } \\
\text { of riverbeds, purchase of modern machinery, construction of adequate information } \\
\text { and communication networks, and other actions to reduce potential hazards) }\left(R_{13}\right) \\
\text { - Planning of funds for implementation of adopted documents }\left(R_{14}\right)\end{array}$ \\
\hline $\begin{array}{l}\text { Resource } \\
\text { management }\left(R_{2}\right)\end{array}$ & $\begin{array}{l}\text { - Understanding sustainable management of resources (water, air, soil, } \\
\text { biodiversity, energy) }\left(R_{21}\right) \\
\text { - Raising awareness in the community for proper resource treatment (education, } \\
\text { training) }\left(R_{22}\right) \\
\text { - Implementation of sustainable resource management practices }\left(R_{23}\right)\end{array}$ \\
\hline $\begin{array}{l}\text { Technical- } \\
\text { technological } \\
\text { security }\left(R_{3}\right)\end{array}$ & $\begin{array}{l}\text { - Implementation of the decision on technical and technological protection } \\
\text { measures against natural and other disasters according to the estimated risk }\left(R_{31}\right) \\
\text { - Providing resistance of critical objects (educational, health, cultural institutions) } \\
\left(R_{32}\right) \\
\text { - Critical infrastructure security (electrical networks, gas pipelines, hot water } \\
\text { pipelines, roads) }\left(R_{33}\right) \\
\text { - Improvement of emergency information and communication networks }\left(R_{34}\right) \\
\text { - Improving the system of monitoring, informing and alarming }\left(R_{35}\right)\end{array}$ \\
\hline $\begin{array}{l}\text { Socio-economic } \\
\text { security }\left(R_{4}\right)\end{array}$ & $\begin{array}{l}\text { - Access to basic social services }\left(R_{41}\right) \\
\text { - Social protection for vulnerable groups }\left(R_{42}\right) \\
\text { - The formation of social networks and humanitarian funds for vulnerable groups } \\
\left(R_{43}\right) \\
\text { - The level of the local economy and employment }\left(R_{44}\right) \\
\text { - Partnership with countries in the region to boost the economy and markets }\left(R_{45}\right)\end{array}$ \\
\hline $\begin{array}{l}\text { Type of disaster } \\
\left(U_{1}\right)\end{array}$ & $\begin{array}{l}\text { - Technical and technological emergencies (fires, explosions, transportation } \\
\text { accidents, accidents at electric power and communal systems) }\left(U_{11}\right) \\
\text { - Natural disasters (floods, landslides, earthquakes, extreme temperatures, natural } \\
\text { fires, infectious diseases) }\left(U_{12}\right) \\
\text { - Anthropogenic emergencies (depletion of non-renewable natural resources, } \\
\text { pollution of environmental media, ozone depletion, biodiversity destruction, mass } \\
\text { animal killing) }\left(U_{13}\right) \\
\text { - War and terrorism }\left(U_{14}\right)\end{array}$ \\
\hline $\begin{array}{l}\text { Protection and } \\
\text { rescue capacities } \\
\text { in emergency } \\
\text { situations }\left(U_{2}\right)\end{array}$ & $\begin{array}{l}\text { - Protection and rescue forces (ministries, authorized and trained legal persons, } \\
\text { fire-fighters, police, army) }\left(U_{21}\right) \\
\text { - Organized civil protection }\left(U_{22}\right) \\
\text { - Employees and voluntary saving societies }\left(U_{23}\right) \\
\text { - Mechanization and modern equipment }\left(U_{24}\right) \\
\text { - Funds for protection and rescue }\left(U_{25}\right)\end{array}$ \\
\hline $\begin{array}{l}\text { Laws and } \\
\text { regulations }\left(U_{3}\right)\end{array}$ & $\begin{array}{l}\text { - Compliance of regulations with international regulations }\left(U_{31}\right) \\
\text { - Mechanisms of regulation changes }\left(U_{32}\right) \\
\text { - Application of regulations }\left(U_{33}\right)\end{array}$ \\
\hline Policies $\left(U_{4}\right)$ & $\begin{array}{l}\text { - Support of institutional structures and policies }\left(U_{41}\right) \\
\text { - Incentives to reduce the vulnerability of protected values }\left(U_{42}\right) \\
\text { - Public-private partnership }\left(U_{43}\right) \\
\text { - Inspection and supervision }\left(U_{44}\right)\end{array}$ \\
\hline
\end{tabular}


Fuzzy AHP method involves the following steps [9]: (1) Identifying and defining a clear goal; (2) Identifying criteria, sub-criteria and alternatives affecting the achievement of the goal; (3) The formation of hierarchical structure; (4) Comparison in pairs (done using fuzzified Saaty's scale); (5) Determination of weight vectors (based on the eigenvector method, the analysis of fuzzy measures, and aggregation principle); (6) Defuzzification and final ranking of alternatives.

When considering the problem of disaster management, there is a need for optimizing the management approach in emergency situations, because this is set as a goal during the analysis. By analysing the process of disaster management, two basic criteria are defined: raising the resistance of local communities in emergency situations $(R)$, and risk management in emergency situations $(E)$. A detailed analysis of criteria identified four sub-criteria for each criterion (Planning $R_{1}$, Resource Management $R_{2}$, Technical and technological security $R_{3}$, Socio-economic security $R_{4}$, Emergency type $E_{1}$, Capacity of protection and rescue $E_{2}$, Legal norms and regulations $E_{3}$, and Policies $E_{4}$ ), and 33 indicators that affect the achievement of the goal. Described problem is presented in form of a hierarchical structure shown in Figure 2.

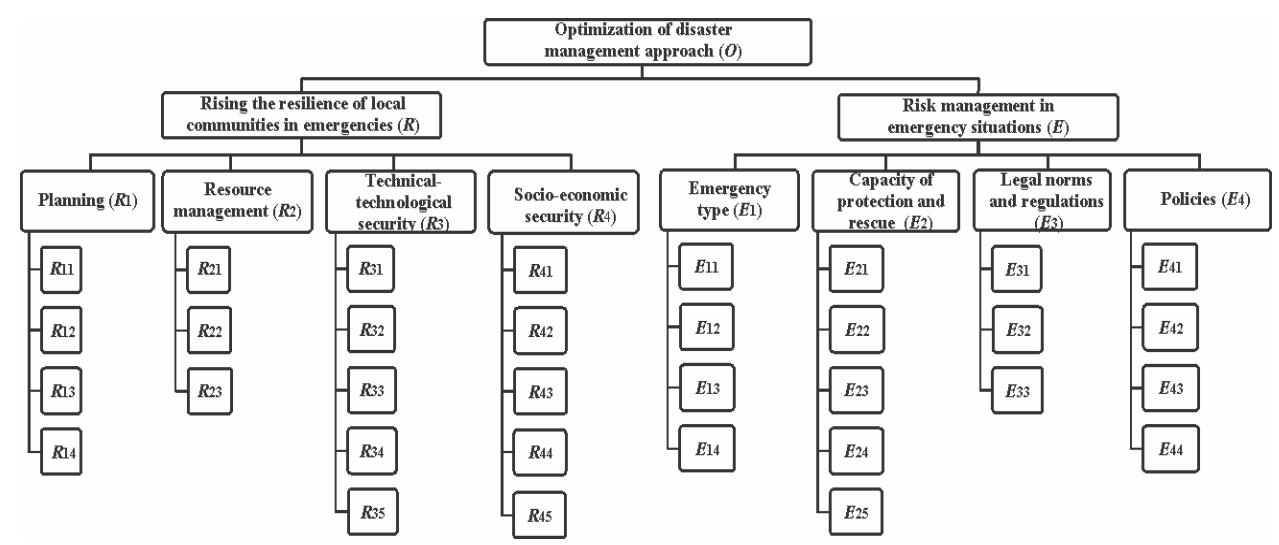

Fig. 2 Hierarchical structure of decision-making to optimize disaster management approach.

Pairs of elements at each level are compared according to their relative contribution to the hierarchical level above (starting from criteria towards alternatives). The decision maker or expert group assess relative contribution of each pair by using the scale 1-9. The following designations are used: $M_{1}=(1,1,1+\delta)$ for equally important alternatives; $M_{3}=(3-\delta, 3,3+\delta)$ for slightly more important alternative; $M_{5}=(5-\delta, 5,5+\delta)$ for more important alternative; $M_{7}=(7-\delta, 7,7+\delta)$ for considerably more important alternative; and $M_{9}=(9-\delta, 9,9)$ for absolutely dominant alternative. Fuzzified scale for comparison in pairs is defined by a fuzzy distance $\delta$, where $0.5 \leq \delta \leq 2$ [12].

The comparison is done in pairs at each level, starting from the top of the hierarchy, and presented in a square matrix form $A=\left[\tilde{a}_{i j}\right]_{i, j=\overline{1, \mathrm{n}}}$, where $\tilde{a}_{i j}$ is the value of the relative importance of each criteria / sub-criteria / alternative $i$ in relation to the criteria / subcriterion / alternative $j$, where $\tilde{a}_{i j}=1$ for $i=j$, and $\tilde{a}_{i j}=1 / \tilde{a}_{j i}$ for $i \neq j$. A detailed description of the procedure can be found in [9] or [20]. After determining the fuzzy weight vectors, to obtain crisp values, defuzzification is done. 


\section{RESULTS AND DISCUSSION}

Results of pairwise comparisons at different levels of the hierarchy presented in Figure 2 are shown in Tables 2-7. In this paper, for the purpose of pairwise comparison of criteria, sub-criteria and indicators, triangular fuzzy numbers with the values of the fuzzy distances of $0.5,1,1.5$ and 2 are applied. $M_{i}$ is a fuzzy number, and $M_{i}^{-1}$ is corresponding reciprocal value, i.e. $M_{i}^{-1}=1 / M_{i}$.

Table 2 Fuzzy comparison of criteria in relation to goal.

\begin{tabular}{|c|c|c|}
\cline { 2 - 3 } \multicolumn{1}{c|}{} & $\boldsymbol{R}$ & $\boldsymbol{E}$ \\
\hline $\boldsymbol{R}$ & $\tilde{1}$ & $M_{3}$ \\
\hline $\boldsymbol{E}$ & $M_{3}{ }^{-1}$ & $\tilde{1}$ \\
\hline
\end{tabular}

Table 3 Fuzzy comparison of sub-criteria in relation to resilience $(R)$ and risk management $(E)$.

\begin{tabular}{|c|c|c|c|c|}
\cline { 2 - 5 } \multicolumn{1}{c|}{} & \multicolumn{4}{c|}{$\boldsymbol{R}$} \\
\cline { 2 - 5 } \multicolumn{1}{c|}{} & $\boldsymbol{R}_{\mathbf{1}}$ & $\boldsymbol{R}_{\mathbf{2}}$ & $\boldsymbol{R}_{\mathbf{3}}$ & $\boldsymbol{R}_{\mathbf{4}}$ \\
\hline $\boldsymbol{R}_{\mathbf{1}}$ & $\tilde{1}$ & $M_{5}$ & $M_{3}$ & $M_{3}$ \\
\hline $\boldsymbol{R}_{\mathbf{2}}$ & $M_{5}{ }^{-1}$ & $\tilde{1}$ & $M_{3}^{-1}$ & $M_{3}{ }^{-1}$ \\
\hline $\boldsymbol{R}_{\mathbf{3}}$ & $M_{3}{ }^{-1}$ & $M_{3}$ & $\tilde{1}$ & $M_{1}$ \\
\hline $\boldsymbol{R}_{\mathbf{4}}$ & $M_{3}{ }^{-1}$ & $M_{3}$ & $M_{1}^{-1}$ & $\tilde{1}$ \\
\hline
\end{tabular}

\begin{tabular}{|c|c|c|c|c|}
\cline { 2 - 5 } \multicolumn{1}{c|}{} & \multicolumn{4}{c|}{$\boldsymbol{E}$} \\
\cline { 2 - 5 } \multicolumn{1}{c|}{} & $\boldsymbol{E}_{\mathbf{1}}$ & $\boldsymbol{E}_{\mathbf{2}}$ & $\boldsymbol{E}_{\mathbf{3}}$ & $\boldsymbol{E}_{\mathbf{4}}$ \\
\hline $\boldsymbol{E}_{\mathbf{1}}$ & $\tilde{1}$ & $M_{5}^{-1}$ & $M_{3}{ }^{-1}$ & $M_{3}{ }^{-1}$ \\
\hline $\boldsymbol{E}_{\mathbf{2}}$ & $M_{5}$ & $\tilde{1}$ & $M_{3}$ & $M_{3}$ \\
\hline $\boldsymbol{E}_{\mathbf{3}}$ & $M_{3}$ & $M_{3}^{-1}$ & $\tilde{1}$ & $M_{1}{ }^{-1}$ \\
\hline $\boldsymbol{E}_{\mathbf{4}}$ & $M_{3}$ & $M_{3}^{-1}$ & $M_{1}$ & $\tilde{1}$ \\
\hline
\end{tabular}

Table 4 Fuzzy comparison of indicators in relation to sub-criteria $R_{1}$ and $R_{2}$.

\begin{tabular}{|c|c|c|c|c|}
\cline { 2 - 5 } \multicolumn{1}{c|}{} & \multicolumn{4}{c|}{$\boldsymbol{R}_{\mathbf{1}}$} \\
\cline { 2 - 5 } \multicolumn{1}{c|}{} & $\boldsymbol{R}_{\mathbf{1 1}}$ & $\boldsymbol{R}_{\mathbf{1 2}}$ & $\boldsymbol{R}_{\mathbf{1 3}}$ & $\boldsymbol{R}_{\mathbf{1 4}}$ \\
\hline $\boldsymbol{R}_{\mathbf{1 1}}$ & $\tilde{1}$ & $M_{3}$ & $M_{3}$ & $M_{5}$ \\
\hline $\boldsymbol{R}_{\mathbf{1 2}}$ & $M_{3}^{-1}$ & $\tilde{1}$ & $M_{1}$ & $M_{3}$ \\
\hline $\boldsymbol{R}_{\mathbf{1 3}}$ & $M_{3}^{-1}$ & $M_{1}{ }^{-1}$ & $\tilde{1}$ & $M_{3}$ \\
\hline $\boldsymbol{R}_{\mathbf{1 4}}$ & $M_{5}^{-1}$ & $M_{3}{ }^{-1}$ & $M_{3}{ }^{-1}$ & $\tilde{1}$ \\
\hline
\end{tabular}

\begin{tabular}{|c|c|c|c|}
\cline { 2 - 4 } \multicolumn{1}{c|}{} & \multicolumn{3}{c|}{$\boldsymbol{R}_{\mathbf{2}}$} \\
\cline { 2 - 4 } \multicolumn{1}{c|}{} & $\boldsymbol{R}_{\mathbf{2 1}}$ & $\boldsymbol{R}_{\mathbf{2 2}}$ & $\boldsymbol{R}_{\mathbf{2 3}}$ \\
\hline $\boldsymbol{R}_{\mathbf{2 1}}$ & $\tilde{1}$ & $M_{3}{ }^{-1}$ & $M_{3}^{-1}$ \\
\hline $\boldsymbol{R}_{\mathbf{2 2}}$ & $M_{3}$ & $\tilde{1}$ & $M_{1}^{-1}$ \\
\hline $\boldsymbol{R}_{\mathbf{2 3}}$ & $M_{3}$ & $M_{1}$ & $\tilde{1}$ \\
\hline
\end{tabular}

Table 5 Fuzzy comparison of indicators in relation to sub-criteria $R_{3}$ and $R_{4}$.

\begin{tabular}{|c|c|c|c|c|c|}
\cline { 2 - 6 } \multicolumn{1}{c|}{} & \multicolumn{5}{c|}{$\boldsymbol{R}_{\mathbf{3}}$} \\
\cline { 2 - 6 } \multicolumn{1}{c|}{} & $\boldsymbol{R}_{\mathbf{3 1}}$ & $\boldsymbol{R}_{\mathbf{3 2}}$ & $\boldsymbol{R}_{\mathbf{3 3}}$ & $\boldsymbol{R}_{\mathbf{3 4}}$ & $\boldsymbol{R}_{\mathbf{3 5}}$ \\
\hline $\boldsymbol{R}_{\mathbf{3 1}}$ & $\tilde{1}$ & $M_{3}$ & $M_{3}$ & $M_{5}$ & $M_{5}$ \\
\hline $\boldsymbol{R}_{\mathbf{3 2}}$ & $M_{3}^{-1}$ & $\tilde{1}$ & $M_{1}^{-1}$ & $M_{3}$ & $M_{3}$ \\
\hline $\boldsymbol{R}_{\mathbf{3 3}}$ & $M_{3}^{-1}$ & $M_{1}$ & $\tilde{1}$ & $M_{3}$ & $M_{3}$ \\
\hline $\boldsymbol{R}_{\mathbf{3 4}}$ & $M_{5}^{-1}$ & $M_{3}^{-1}$ & $M_{3}^{-1}$ & $\tilde{1}$ & $M_{1}$ \\
\hline $\boldsymbol{R}_{\mathbf{3 5}}$ & $M_{5}^{-1}$ & $M_{3}^{-1}$ & $M_{3}^{-1}$ & $M_{1}^{-1}$ & $\tilde{1}$ \\
\hline
\end{tabular}

\begin{tabular}{|c|c|c|c|c|c|}
\cline { 2 - 6 } \multicolumn{1}{c|}{} & \multicolumn{5}{c|}{$\boldsymbol{R}_{\mathbf{4}}$} \\
\cline { 2 - 6 } \multicolumn{1}{c|}{} & $\boldsymbol{R}_{\mathbf{4 1}}$ & $\boldsymbol{R}_{\mathbf{4 2}}$ & $\boldsymbol{R}_{\mathbf{4 3}}$ & $\boldsymbol{R}_{\mathbf{4 4}}$ & $\boldsymbol{R}_{\mathbf{4 5}}$ \\
\hline $\boldsymbol{R}_{\mathbf{4 1}}$ & $\tilde{1}$ & $M_{1}^{-1}$ & $M_{1}$ & $M_{3}^{-1}$ & $M_{3}^{-1}$ \\
\hline $\boldsymbol{R}_{\mathbf{4 2}}$ & $M_{1}$ & $\tilde{1}$ & $M_{1}$ & $M_{3}^{-1}$ & $M_{3}^{-1}$ \\
\hline $\boldsymbol{R}_{\mathbf{4 3}}$ & $M_{1}^{-1}$ & $M_{1}^{-1}$ & $\tilde{1}$ & $M_{3}^{-1}$ & $M_{3}^{-1}$ \\
\hline $\boldsymbol{R}_{\mathbf{4 4}}$ & $M_{3}$ & $M_{3}$ & $M_{3}$ & $\tilde{1}$ & $M_{1}$ \\
\hline $\boldsymbol{R}_{\mathbf{4 5}}$ & $M_{3}$ & $M_{3}$ & $M_{3}$ & $M_{1}^{-1}$ & $\tilde{1}$ \\
\hline
\end{tabular}


Table 6 Fuzzy comparison of indicators in relation to sub-criteria $E_{1}$ and $E_{2}$.

\begin{tabular}{|c|c|c|c|c|}
\cline { 2 - 5 } \multicolumn{1}{c|}{} & \multicolumn{4}{c|}{$\boldsymbol{E}_{\mathbf{1}}$} \\
\cline { 2 - 5 } \multicolumn{1}{c|}{} & $\boldsymbol{E}_{\mathbf{1 1}}$ & $\boldsymbol{E}_{\mathbf{1 2}}$ & $\boldsymbol{E}_{\mathbf{1 3}}$ & $\boldsymbol{E}_{\mathbf{1 4}}$ \\
\hline $\boldsymbol{E}_{\mathbf{1 1}}$ & $\tilde{1}$ & $M_{1}$ & $M_{3}$ & $M_{5}$ \\
\hline $\boldsymbol{E}_{\mathbf{1 2}}$ & $M_{1}{ }^{-1}$ & $\tilde{1}$ & $M_{1}{ }^{-1}$ & $M_{3}$ \\
\hline $\boldsymbol{E}_{\mathbf{1 3}}$ & $M_{3}^{-1}$ & $M_{1}$ & $\tilde{1}$ & $M_{1}$ \\
\hline $\boldsymbol{E}_{\mathbf{1 4}}$ & $M_{5}^{-1}$ & $M_{3}^{-1}$ & $M_{1}^{-1}$ & $\tilde{1}$ \\
\hline
\end{tabular}

\begin{tabular}{|c|c|c|c|c|c|}
\cline { 2 - 6 } \multicolumn{1}{c|}{} & \multicolumn{5}{c|}{$\boldsymbol{E}_{\mathbf{2}}$} \\
\cline { 2 - 6 } \multicolumn{1}{c|}{} & $\boldsymbol{E}_{\mathbf{2 1}}$ & $\boldsymbol{E}_{\mathbf{2 2}}$ & $\boldsymbol{E}_{\mathbf{2 3}}$ & $\boldsymbol{E}_{\mathbf{2 4}}$ & $\boldsymbol{E}_{\mathbf{2 5}}$ \\
\hline $\boldsymbol{E}_{\mathbf{2 1}}$ & $\tilde{1}$ & $M_{3}$ & $M_{3}$ & $M_{1}$ & $M_{1}$ \\
\hline $\boldsymbol{E}_{\mathbf{2 2}}$ & $M_{3}{ }^{-1}$ & $\tilde{1}$ & $M_{1}$ & $M_{3}{ }^{-1}$ & $M_{3}{ }^{-1}$ \\
\hline $\boldsymbol{E}_{\mathbf{2 3}}$ & $M_{3}{ }^{-1}$ & $M_{1}^{-1}$ & $\tilde{1}$ & $M_{3}{ }^{-1}$ & $M_{3}{ }^{-1}$ \\
\hline $\boldsymbol{E}_{\mathbf{2 4}}$ & $M_{1}{ }^{-1}$ & $M_{3}$ & $M_{3}$ & $\tilde{1}$ & $M_{1}{ }^{-1}$ \\
\hline $\boldsymbol{E}_{\mathbf{2 5}}$ & $M_{1}^{-1}$ & $M_{3}$ & $M_{3}$ & $M_{1}$ & $\tilde{1}$ \\
\hline
\end{tabular}

Table 7 Fuzzy comparison of indicators in relation to sub-criteria $E_{3}$ and $E_{4}$.

\begin{tabular}{|c|c|c|c|}
\cline { 2 - 4 } \multicolumn{1}{c|}{} & \multicolumn{3}{c|}{$\boldsymbol{E}_{\mathbf{3}}$} \\
\cline { 2 - 4 } \multicolumn{1}{c|}{} & $\boldsymbol{E}_{\mathbf{3 1}}$ & $\boldsymbol{E}_{\mathbf{3 2}}$ & $\boldsymbol{E}_{\mathbf{3 3}}$ \\
\hline $\boldsymbol{E}_{\mathbf{3 1}}$ & $\tilde{1}$ & $M_{3}$ & $M_{3}$ \\
\hline $\boldsymbol{E}_{\mathbf{3 2}}$ & $M_{3}^{-1}$ & $\tilde{1}$ & $M_{1}$ \\
\hline $\boldsymbol{E}_{\mathbf{3 3}}$ & $M_{3}^{-1}$ & $M_{1}^{-1}$ & $\tilde{1}$ \\
\hline
\end{tabular}

\begin{tabular}{|c|c|c|c|c|}
\cline { 2 - 5 } \multicolumn{1}{c|}{} & \multicolumn{4}{c|}{$\boldsymbol{E}_{\mathbf{4}}$} \\
\cline { 2 - 5 } \multicolumn{1}{c|}{} & $\boldsymbol{E}_{\mathbf{4 1}}$ & $\boldsymbol{E}_{\mathbf{4 2}}$ & $\boldsymbol{E}_{\mathbf{4 3}}$ & $\boldsymbol{E}_{\mathbf{4 4}}$ \\
\hline $\boldsymbol{E}_{\mathbf{4 1}}$ & $\tilde{1}$ & $M_{1}$ & $M_{3}$ & $M_{3}$ \\
\hline $\boldsymbol{E}_{\mathbf{4 2}}$ & $M_{1}^{-1}$ & $\tilde{1}$ & $M_{3}$ & $M_{3}$ \\
\hline $\boldsymbol{E}_{\mathbf{4 3}}$ & $M_{3}^{-1}$ & $M_{3}^{-1}$ & $\tilde{1}$ & $M_{1}$ \\
\hline $\boldsymbol{E}_{\mathbf{4 4}}$ & $M_{3}^{-1}$ & $M_{3}^{-1}$ & $M_{1}^{-1}$ & $\tilde{1}$ \\
\hline
\end{tabular}

After determining the fuzzy weight vectors, defuzzification using mean aggregated weight (MAW) method is performed. The final weights $(W)$ and final ranks $(F)$ of individual indicators for different $\delta$ values $\left(\delta_{1}=0.5 ; \delta_{2}=1 ; \delta_{3}=1.5 ; \delta_{4}=2\right)$ are shown in Figures 3-6.

The results show that for optimization of risk management in emergency situations it is significantly important to raise the resistance of the community, as a preventive measure of protection against disasters, and risk management when disasters occur. However, preference should be given to prevention, by raising the community resilience to disasters. At the second hierarchical level, as the most important among the subcriteria, planning and capacities for protection and rescue are identified. Planning develops the conditions for building a disaster resilient society, developing an integrated and efficient system of protection and rescue, where the existing capacities to protect and rescue are the most important links in risk management after a disaster happens.

At the level of indicators, the influence of fuzzy distance $(\delta)$ on final ranking of alternatives is analysed. To determine the impact of fuzzy distance on the final ranking of indicators, we used the values from accepted boundaries of triangular fuzzy numbers $(0.5 \leq \delta \leq 2): \delta_{1}=0.5 ; \delta_{2}=1 ; \delta_{3}=1.5 ; \delta_{4}=2$. The results presented in Figures $3-6$ show that the effect is not large, or that ranks of only few indicators are slightly changed. Within ten first-ranked indicators, only two indicators are with different ranks for $\delta=2$ (Making protection and rescue plans $\left(R_{13}\right)$, and Implementation of decisions on technical/technological protection measures $\left(R_{31}\right)$ ). This allows us to discuss the order of relevant indicators. 


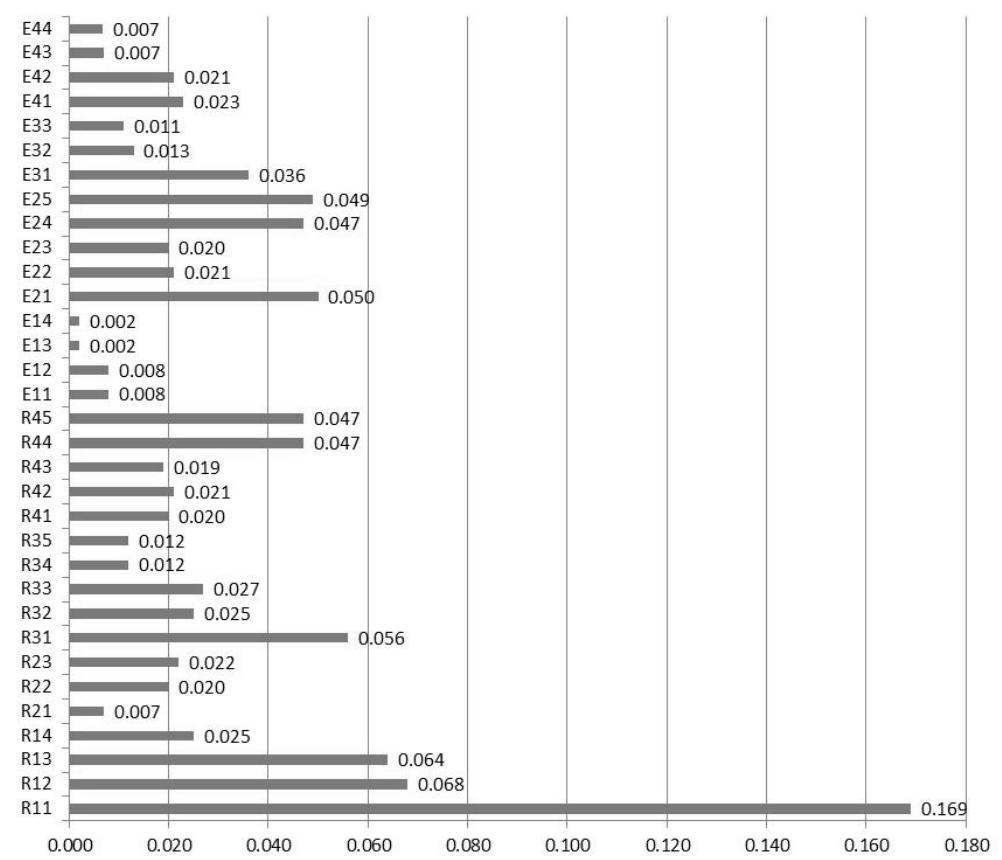

Fig. 3 Indicator weights for $\delta_{1}=0.5$.

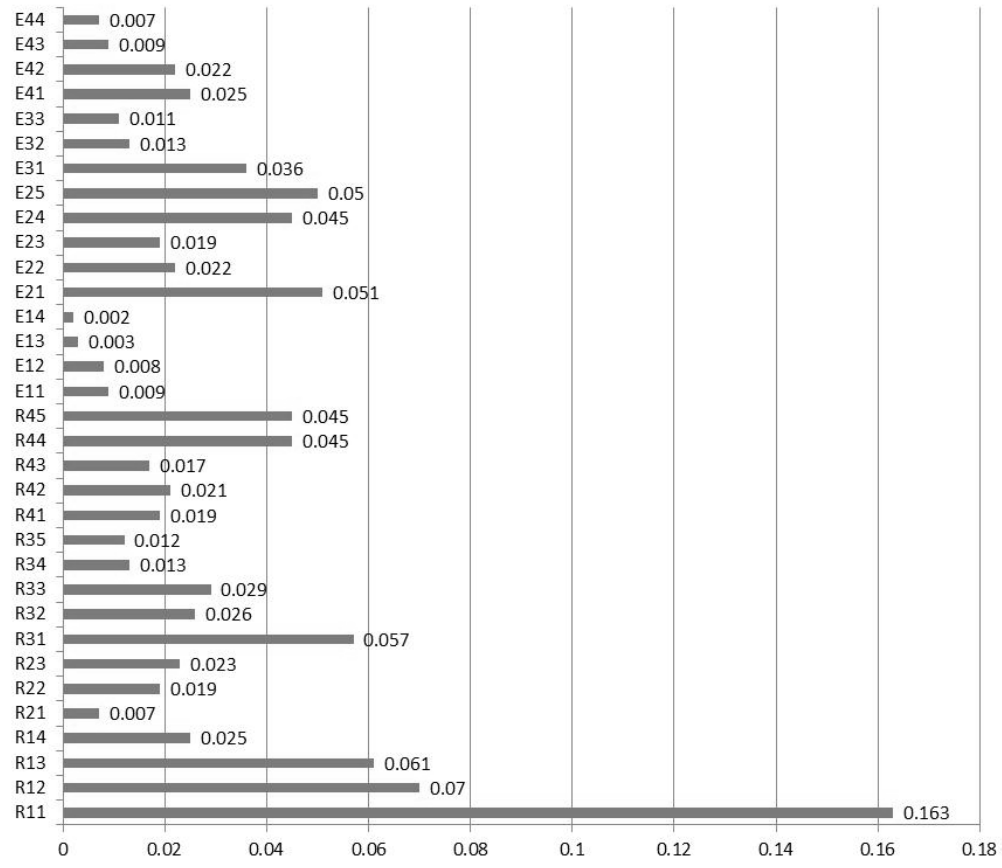

Fig. 4 Indicator weights for $\delta_{2}=1$. 


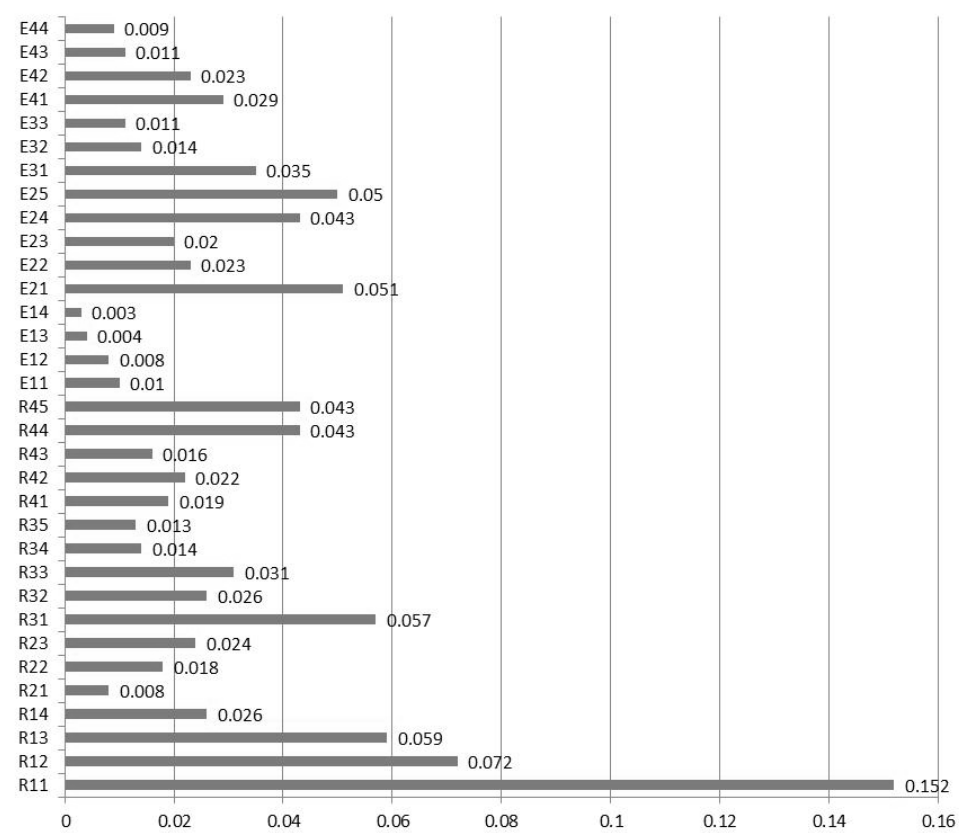

Fig. 5 Indicator weights for $\delta_{3}=1.5$.

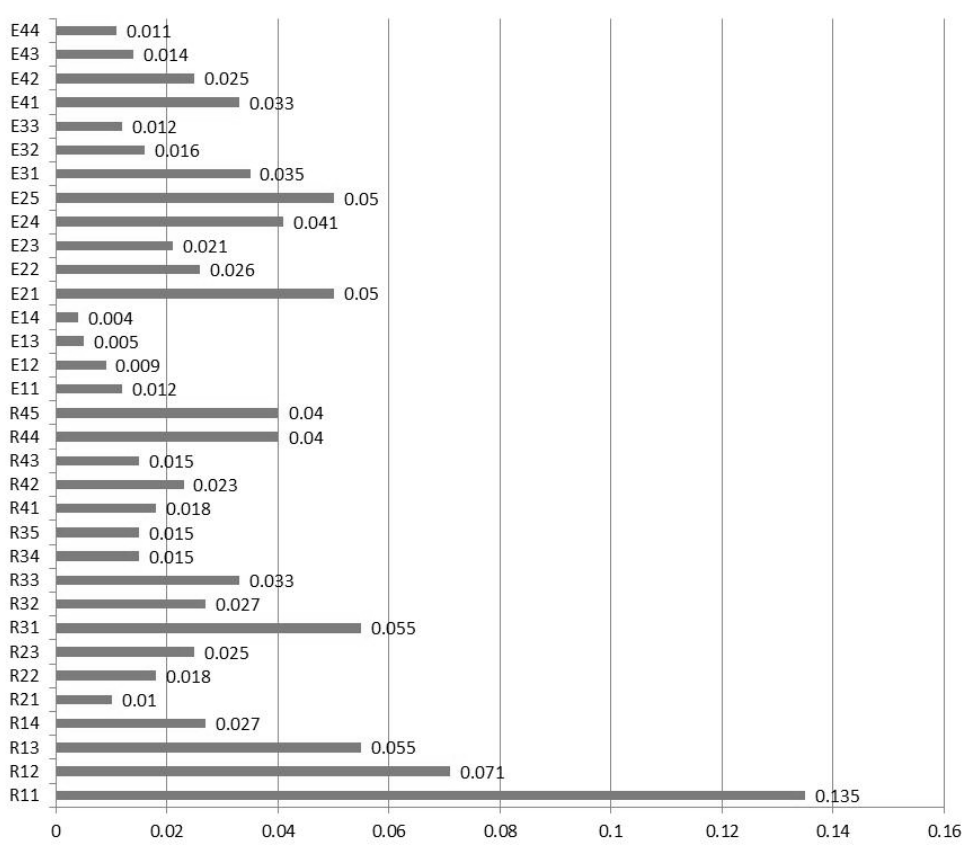

Fig. 6 Indicator weights for $\delta_{4}=2$. 
Top ranked indicators are from the Planning group (adoption of local security strategy, risk assessment plan development, and making protection and rescue plans). They are followed by the indicators from the "Protection and rescue capacities in emergency situations" group (forces and funds for protection and rescue, machinery and modern equipment), then from the group of indicators of socio-economic security (level of local economy and employment, partnership with countries in the region), as well as indicators related to implementation of technical/technological measures of protection and compliance of domestic regulations with international regulations. The worst ranked indicators are related to different types of emergencies, which indicates that the type of emergency does not interfere with the effectiveness of risk management if local community has satisfactory level of disaster resilience and capacity to protect and rescue in accordance with vulnerability assessment and corresponding protection and rescue plans.

\section{CONCLUSION}

Disasters show how a society is vulnerable (or resilient), and in what way is ready to respond. Disaster risk management is a way to reduce risks, to limit unwanted consequences, and to increase the resilience of a society to disasters. The Republic of Serbia has the Law on emergency situations promoting an integrated protection and rescue system. However, the current level of organization and training of integrated protection and rescue is significantly inferior to estimated needs. Disaster risk reduction requires strong institutional basis, which can be achieved through capacity building, promotion of corresponding policies and legislations, effective coordination mechanisms and good governance. The management should be supported by corresponding indicators whose values indicate a way to prevent or respond to different threats.

The paper defines resilience and risk management indicators at the level of local communities. The analysis of the importance of these indicators was conducted with the fuzzy AHP method. The results show the importance of raising the resilience of local communities to disasters, and indicate dominant indicators on which should be given special attention during continuous optimizing the process of natural disaster and technological accident management. The framework for disaster risk management at local level, based on resilience indicators and multi-criteria analysis, can be applied in the process of continuous improvement of local defence system against natural disasters and technological accidents.

\section{REFERENCES}

1. Savić, S., Stanković, A. (2015), Indikatori rizika u vanrednim situacijama, 18. nacionalna konferencija "Upravljanje kvalitetom i pouzdanošću", Prijevor, Srbija, 25-26. juni 2015, Zbornik radova, 310-317, Istraživački centar DQM, Prijevor.

2. Benson C. (2004), Macroeconomic Concepts of Vulnerability: Dynamics, Complexity and Public Policy, In: Mapping Vulnerability: Disasters, Development and People (eds. G. Bankoff, G. Frerks and D. Hilhorst), Earthscan Publishers, London, 2004.

3. Briguglio L., Cordina G., Bugeja S., Farrugia N. (2005), The Development of an Index on Economic Resilience, International Workshop on Building the Economic Resilience of Small Status, Commonwealth Secretariat and Department of Economics of University of Malta, Valletta. 
4. Davidson R. (1997), Urban Earthquake Disaster Risk Index, Report No 121, The John A. Blume Earthquake Engineering Center, Department of Civil Engineering, Stanford University, Stanford, 1997. https://blume.stanford.edu/blume-tech-reports (Accessed: 09.01.2017.)

5. Indicators of disaster risk and risk management: Program for Latin America and the Caribbean, Summary Report, Inter-American Development Bank (IADB), Washington D. C., 2010. http://idbdocs.iadb.org/ wsdocs/getdocument.aspx?docnum=35177671 (Accessed: 09.01.2017.)

6. Saisana M., Tarantola S. (2002), State-of-the-art Report on Current Methodologies and Practices for Compozite Indicator Development, Applied Statistics Group, Joint Research Centre, European Commission, Institute for Protection and Security of Citizen Technological and Economic Risk Management, Ispra. https://bookshop.europa.eu (Accessed: 09.01.2017.)

7. UN International Strategy for Disaster Reduction (UNISDR) (2007), Building Disaster Resilient Communities - Good Practices and Lessons Learned, A Publication of the "Global Network of NGOs" for Disaster Risk Reduction, Geneva. http://www.unisdr.org/we/inform/publications /596 (Accessed: 09.01.2017.)

8. Eakin H., Bojorquez-Tapia L.A. (2008), Insights into the composition of household vulnerability from multi-criteria decision analysis, Global Environmental Change, 18(1), 112-127.

9. Janaćković G., Savić S., Stanković M. (2013), Selection and ranking of occupational safety indicators based on fuzzy AHP: Case study in road construction companies, South African Journal of Industrial Engineering, 24(3), 175-189.

10. Janaćković G., Savić S., Stanković M. (2011), Multi-criteria decision analysis in occupational safety management systems, Safety Engineering, 1(1), 17-23.

11. Orencio P.M., Fujii M. (2013), A Localized disaster-resilience index to assess coastal communities based on an Analytical Hierarchy Process (AHP), International Journal of Disaster Risk Reduction, 3(3), 62-75.

12. Srđević B., Medeiros Y. (2008), Fuzzy AHP Assessment of Water Management Plans, Water Resources Management, 22, 877-894.

13. Yang X., Zhou J., Ding J., Zou Q., Zhang Y. (2012), A fuzzy AHP-TFN based evaluation model of flood risk analysis, Journal of Computational Information Systems, 8(22), 9281-9289.

14. Birkmann, J. (2006), Measuring vulnerability to promote disaster-resilient societies: Conceptual frameworks and definitions, in: Measuring Vulnerability to Natural Hazards: towards disaster resilient societies, edited by: Birkmann, J., United Nations University Press, Tokyo, 9-54.

15. Carreno M.L., Cardona O.D., Barbat A.H. (2007), A disaster risk management performance index, Natural Hazards, 41(1), 1-20.

16. Cutter S.L., Burton C.G., Emrich C.T. (2010), Disaster resilience indicators for benchmarking baseline conditions, Journal of Homeland Security and Emergency Management, 7(1), 1-22.

17. Sherrieb K., Norris F.H., Galea, S. (2010), Measuring capacities for community resilience, Social Indicators Research, 99(2), 227-247.

18. Twigg J. (2009), Characteristics of a Disaster-Resilient Community, A GUIDANCE NOTE, Version 2, http://community.eldis.org/.59e907ee/Characteristics2 EDITION.pdf (Accessed: 09.01.2017.)

19. UN Development Programme (UNDP) (2004), Reducing Disaster Risk: A Challenge for Development, A Global Report, Chapter 2: International Patterns of Risk, the Disaster Risk Index, DRI, Geneva. http://www.planat.ch/fileadmin/PLANAT/planat_pdf/alle_2012/2001-

2005/Pelling_Maskrey_et_al_2004_-_Reducing_Disaster_Risk.pdf (Accessed: 09.01.2017.)

20. Janjić A., Savić S., Janaćković G., Stanković M., Velimirović L., (2016), Multi-criteria assessment of the Smart Grid efficiency using the fuzzy analytic hierarchy process, Facta Universitatis, Series: Electronics and Energetics, 29 (4), 631-646. 


\section{OKVIR ZA OPTIMIZACIJU UPRAVLJANJA RIZIKOM OD KATASTROFA U LOKALNIM ZAJEDNICAMA ZASNOVAN NA INDIKATORIMA}

Efekti na funkcionisanje društva i posledice vanrednih situacija i tehnoloških udesa zahtevaju pripremljenost $i$ brzo reagovanje. Upravljanje vanrednim situacijama zasniva se na odlučivanju baziranom na opisu situacije i potencijalnim opasnostima. Razmatranje opasnosti obavlja se na različitim nivoima, od nacionalnog do lokalnog nivoa. U radu je prikazan okvir za optimizaciju upravljanja rizicima od katastrofa i tehnoloških udesa na lokalnom nivou zasnovan na korišćenju indikatora rizika. Primenom metoda višekriterijumske analize, izabrani su ključni indikatori koji najviše opisuju rizike na nivou lokalnih zajednica u Srbiji. Rezultati pokazuju značaj podizanja otpornosti lokalnih zajednica na katastrofe, pre svega u domenu planiranja i razvijanja kapaciteta.

Ključne reči: indikatori, rizik, žilavost, upravljanje, fazi AHP 